\title{
阿拉华蜡孔菌中四个新的 2,5-二取代呋喃邻二醇
}

\author{
刘良燕 ${ }^{a}$ 冯 涛 ${ }^{b} \quad$ 李正辉 $^{b}$ 刘吉开 ${ }^{*, b}$ \\ ( ${ }^{a}$ 云南农业大学农学与生物技术学院 昆明 650201) \\ ( ${ }^{b}$ 中南民族大学药学院 武汉 430074)
}

\begin{abstract}
摘要 从阿拉华蜡孔菌发酵液中分离鉴定四个呋喃邻二醇, $1 R, 2 R-1$-[5-(戊-4-烯-1-基)呋喃-2-基]丙烷-1,2-二醇(1), $1 S, 2 R$-1-[5-(戊-4-烯-1-基)呋喃-2-基]丙烷-1,2-二醇(2)、1R,2R-1-[(5-戊基)呋喃-2-基]丙烷-1,2-二醇(3)和 1R,2S-1-[(5-成基) 呋喃-2-基]丙烷-1,2-二醇(4). 综合运用波谱分析(1D、2D NMR, HRMS)、化学法(异丙叉衍生物)和乙酸锄二聚体 $\left[\mathrm{Mo}_{2}(\mathrm{OAc})_{4}\right]$ 诱导 $\mathrm{CD}$ 谱等方法确定了化合物 $\mathbf{1} \sim \mathbf{4}$ 的绝对构型. 关键词 邻二醇; 阿拉华蜡孔菌; 诱导 $\mathrm{CD}$ 谱; 乙酸钿二聚体
\end{abstract}

\section{Four New 2,5-Disubstituted Furan Vicinal Diols from the Fungus Ceriporia alachuana}

\author{
Liu, Liangyan $^{a} \quad$ Feng, Tao $^{b} \quad$ Li, Zhenghui $^{b} \quad$ Liu, Jikai $^{*, b}$ \\ ( ${ }^{a}$ College of Agronomy and Biotechnology, Yunnan Agricultural University, Kunming 650201) \\ ( ${ }^{b}$ School of Pharmaceutical Sciences, South-Central University for Nationalities, Wuhan 430074)
}

\begin{abstract}
Four new closely related vicinal diols, (1R,2R)-1-(5-(pent-4-en-1-yl)furan-2-yl)propane-1,2-diol (1), (1S,2R)-1-(5(pent-4-en-1-yl)furan-2-yl)propane-1,2-diol (2), (1R,2R)-1-(5-pentylfuran-2-yl)propane-1,2-diol (3) and (1R,2S)-1-(5-pentylfuran-2-yl)propane-1,2-diol (4), were isolated from the cultures of the fungus Ceriporia alachuana. Their structures and absolute configurations were totally determined by spectroscopic means, chemical method (forming di- $O$-isopropylidene derivative) and $\mathrm{Mo}_{2}(\mathrm{OAc})_{4}$ induced circular dichroism (ICD) experiments.

Keywords vicinal diols; Ceriporia alachuana; induced circular dichroism (ICD); dimolybdenum tetraacetate
\end{abstract}

The vicinal diol group widely present in many types of natural products, e.g. saccharides, vitamins, nucleotides, steriods, sphingolipids, macrolides and terpenoids, is an important functional group for maintaining biological activities. ${ }^{[1 \sim 4]}$ In organic chemistry, vicinal diols are important chiral synthesis building blocks which can be used as valuable controlling structures in asymmetric synthesis. ${ }^{[5]}$ However, the determination of the absolute configuration of vicinal diols is not an easy work even though state-of-the-art instruments have been widely adopted in natural product chemistry. In 1972, Harada and Nakanish ${ }^{[6]}$ reported the exciton chirality method to determine the absolute configurations of a series of cyclic vicinal diols by circular dichroism spectrum. However, this method was proven to be inefficient on acyclic vicinal diols since several conformers with different spectroscopic properties coexisted in solution. ${ }^{[7]}$ In order to determine acyclic vicinal diols, various alternative techniques were established, mainly exploiting optical properties of transition metal complex. ${ }^{[8 \sim 13]}$ The method employing dimolybdenum tetraacetate $\left[\mathrm{Mo}_{2}-\right.$ $\left.(\mathrm{OAc})_{4}\right]$ is regarded as the most convenient and reliable, which can be used for assigning the absolute configuration of natural vicinal diols. ${ }^{[14,15]}$

In this paper, we apply the $\mathrm{Mo}_{2}(\mathrm{OAc})_{4}$ induced circular dichroism (ICD) to determine the absolute configuration of four new 2,5-disubstituted furan vicinal diols, namely, $(1 R$, 2R)-1-(5-(pent-4-en-1-yl)furan-2-yl)propane-1,2-diol (1), $(1 S, 2 R)-1-(5-($ pent-4-en-1-yl)furan-2-yl)propane-1,2-diol (2), (1R,2R)-1-(5-pentylfuran-2-yl)propane-1,2-diol (3) and $(1 R, 2 S)-1-(5-p e n t y l f u r a n-2-y l) p r o p a n e-1,2-d i o l ~(4)$, which were isolated from the cultures of the fungus Ceriporia alachuana (Figure 1).

\section{Results and discussion}

Compound 1 was assigned with a molecular formula of $\mathrm{C}_{12} \mathrm{H}_{18} \mathrm{O}_{3}$ according to HREIMS spectrum at $\mathrm{m} / \mathrm{z} 210.1257$ (calcd for $\mathrm{C}_{12} \mathrm{H}_{18} \mathrm{O}_{3}$ 210.1256). In accordance with its mo-

* Corresponding author. E-mail: jkliu@mail.kib.ac.cn

Received January 7, 2017; revised and published online January 20, 2017

Project supported by the National Natural Science Foundation of China (Nos. 21502167, 81561148013). 

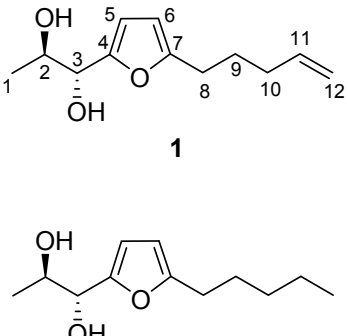

$\overline{\mathrm{O}} \mathrm{H}$
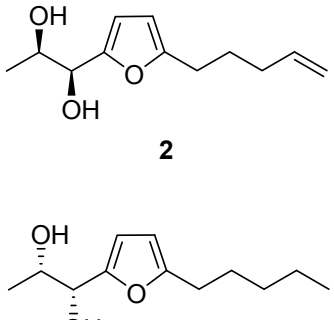

$\overline{\mathrm{O}} \mathrm{H}$
Figure 1 Structures of compounds $1 \sim 4$

lecular formula, all the 12 carbons including one methyl, four methylenes, three methines and two quaternary carbons were well resolved in the ${ }^{13} \mathrm{C}$ NMR (DEPT) spectrum. One 2,5-disubstituted furan moiety was constructed from the proton signals at $\delta_{\mathrm{H}} 6.16(\mathrm{~d}, J=2.8 \mathrm{~Hz}, 1 \mathrm{H})$ and $5.96(\mathrm{~d}$, $J=2.8 \mathrm{~Hz}, 1 \mathrm{H})$, as well as the characteristic carbons at $\delta_{\mathrm{C}}$ 155.4 (C-4), 107.8 (C-5), 106.2 (C-6) and 155.1 (C-7). The protons at $\delta_{\mathrm{H}} 5.83(\mathrm{~m}, 1 \mathrm{H}), 5.02(\mathrm{~d}, J=17.1 \mathrm{~Hz}, 1 \mathrm{H})$ and $4.95(\mathrm{~d}, J=10.2 \mathrm{~Hz}, 1 \mathrm{H})$ in the ${ }^{1} \mathrm{H}$ NMR spectrum manifested a terminal double bond. In the ${ }^{1} \mathrm{H}-{ }^{1} \mathrm{H}$ COSY spectrum, the consecutive correlations of $\mathrm{H}-8 / \mathrm{H}-9 / \mathrm{H}-10 / \mathrm{H}-11 /$ $\mathrm{H}-12$ established the pent-4-enyl group, which was further determined to be linked with furan moiety by $\mathrm{C}(7)-\mathrm{C}(8)$ based on the HMBC correlations from $\mathrm{H}-8$ to $\mathrm{C}-6$, from $\mathrm{H}-9$ to $\mathrm{C}-7$ and from H-6 to C-8. Similarly, apropane-1,2-diol group was manifested from the ${ }^{1} \mathrm{H}-{ }^{1} \mathrm{H}$ COSY correlations of $\mathrm{OH}-2 / \mathrm{H}-2, \mathrm{OH}-3 / \mathrm{H}-3$ and $\mathrm{H}-1 / \mathrm{H}-2 / \mathrm{H}-3$. The linkage between $\mathrm{C}-3$ and $\mathrm{C}-4$ was deduced from the correlation from $\mathrm{H}-2$ to $\mathrm{C}-4$, and from $\mathrm{H}-3$ to $\mathrm{C}-4$ and $\mathrm{C}-5$ in the HMBC spectrum. Therefore, the planar structure of 1 was established to be 1-(5-(pent-4-en-1-yl)furan-2-yl)propane-1,2diol as shown in Figure 2.

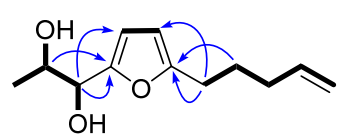

$1 / 2$

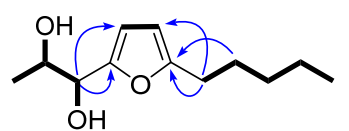

$3 / 4$

\section{$\longrightarrow{ }^{1} \mathrm{H}^{1} \mathrm{HCOSY} \rightleftharpoons \mathrm{HMBC}$}

Figure 2 Key ${ }^{1} \mathrm{H}^{1}{ }^{1} \mathrm{H} \mathrm{COSY}$ and $\mathrm{HMBC}$ correlations of $\mathbf{1} \sim \mathbf{4}$

In order to determine the relative stereochemistry, compound 1 was reacted with 2,2-dimethoxypropane to yield its di-O-isopropylidene derivative 1a. Subsequent ROESY experiment of 1a manifested that $\mathrm{H}-1$ and $\mathrm{H}-2$ showed correlation with the same methyl on isopropyl. ${ }^{[16]}$ Therefore compound 1 was deduced to be an erythro-form vicinal diol (Scheme 1).

With the characterization of the relative configuration, dimolybdenum tetraacetate $\left[\mathrm{Mo}_{2}(\mathrm{OAc})_{4}\right]$ induced $\mathrm{CD}$ (ICD) spectrum was applied to determine the absolute configuration of 1. ${ }^{[1]}$ According to the Snatzke's rule, the positive torsional angle of the $\mathrm{O}-\mathrm{C}-\mathrm{C}-\mathrm{O}$ moiety leads to the positive Cotton effect at about $310 \mathrm{~nm}$, and vice versa. As shown in Figure 3, the ICD spectrum of 1 showed a positive Cotton effect at $300 \sim 350 \mathrm{~nm}$, suggesting a positive torsional angle of the $\mathrm{O}-\mathrm{C}-\mathrm{C}-\mathrm{O}$ moiety. In order to form a positive torsional angle, the $2 R, 3 R$-form could maintain the favored conformation $(\mathbf{1 A})$ in which the bulky furan and $\mathrm{O}-\mathrm{C}-\mathrm{C}-\mathrm{O}$ center stayed away from each other; however, for the $2 S, 3 S$-form (1B), the two bulky groups should be adjacent with high steric hindrance, which is unfavorable (Scheme 2). From the above analysis, the absolute configuration of 1 was determined to be $2 R, 3 R$.

Compound 2 shared the same HREIMS and almost identical 1D and 2D NMR spectra with 1, revealing the same planar structure. The minor difference in their NMR spectra, mainly on C-1, C-2 and C-3 positions, should be ascribed to the structural variation of the vicinal diol group. To determine the stereochemistry of the diol, corresponding di- $O$-isopropylidene derivative (2a) was synthesized and its ROESY experiment was performed. Different from 1a, H-1 and $\mathrm{H}-2$ showed obvious correlations with different methyls of the isopropyl moiety in the REOSY spectrum of $\mathbf{2 a}$, verifying compound $\mathbf{2}$ to be a threo-form vicinal diol. The ICD spectrum of $\mathbf{2}$ exhibited a negative Cotton effect at $300 \sim 350 \mathrm{~nm}$, corresponding to a negative torsional angle of $\mathrm{O}-\mathrm{C}-\mathrm{C}-\mathrm{O}$ moiety. So the absolute configuration of 2 was determined to be $1 S, 2 R$.

Compound 3 was identified with the molecular formula of $\mathrm{C}_{12} \mathrm{H}_{20} \mathrm{O}_{3}$ from the molecular ion peak at $\mathrm{m} / z 212.1416$ (calcd for $\mathrm{C}_{12} \mathrm{H}_{20} \mathrm{O}_{3}$ 212.1412) in HREIMS. The ${ }^{1} \mathrm{H}$ NMR and ${ }^{13} \mathrm{C}$ NMR data of $\mathbf{3}$ resembled those of $\mathbf{1}$, except for the terminal double bond in $\mathbf{1}$ being saturated as an ethyl in $\mathbf{2}$. This was confirmed by the cross peaks of $\mathrm{H}-8 / \mathrm{H}-9$ / $\mathrm{H}-10 / \mathrm{H}-11 / \mathrm{H}-12$ in ${ }^{1} \mathrm{H}-{ }^{1} \mathrm{H}$ COSY spectrum. Detailed analysis on the HMBC and ${ }^{1} \mathrm{H}^{-1} \mathrm{H}$ COSY spectra revealed the planar structure of $\mathbf{3}$ as 1-(5-pentylfuran-2-yl)- propane-1,2-diol, dihydro-derivative of $\mathbf{1}$. Its di-O-isopropylidene derivative (3a) was synthesized and measured for ROESY experiment, in which H-2 and H-3 displayed correlations with the same methyl on the isopropyl group, indicating the erythro-form of 3. Subsequent $\mathrm{Mo}_{2}(\mathrm{OAc})_{4}$ ICD experiment displayed the positive Cotton effect at about $350 \mathrm{~nm}$, which is indicative for $1 R, 2 R$-configuration. Compound 4 was deduced to maintain the same molecular formula and planar structure with $\mathbf{3}$ from their almost identical HRESIMS, 1D and 2D NMR data. The structural difference between $\mathbf{3}$ and $\mathbf{4}$ is only in the vicinal diol group. Consequently, the di- $O$-isopropylidene derivative (4a) was synthesized, and ROESY experiment was made. Different from 3a, H-2 and H-3 gave ROESY correlations to different methyls on the isopropyl moiety in the ROESY spectrum of 4a, verifying the threo configuration. In the ICD spectrum of 4 , the positive Cotton effect at about $350 \mathrm{~nm}$ revealed the absolute stereochemistry to be $1 R, 2 S$.

\section{Conclusions}

In conclusion, four closely related vicinal diols $\mathbf{1} \sim \mathbf{4}$ were isolated from the cultures of the fungus Ceriporia alachuana. Their absolute configuration was totally deter- 
<smiles>C=CCCCc1ccc([C@@H](O)C(C)O)o1</smiles>

1<smiles>C=CCCCc1ccc(C(C)OC(C)(C)C)o1</smiles><smiles>C=CCCCc1ccc([C@@H](O)C(C)O)o1</smiles><smiles>C=CCCCc1ccc(C2OC(C)(C)OC2C)o1</smiles><smiles>C[CH2+]CCCCc1ccc([C@@H](O)C(C)O)o1</smiles><smiles>CCCCCc1ccc(CC(C)OC(C)(C)C)o1</smiles><smiles>CCCCCc1ccc([C@@H](O)C(C)O)o1</smiles><smiles>COC(C)(C)OCCOCCO</smiles><smiles>CCCCCc1ccc(C(C)O)o1</smiles>

4

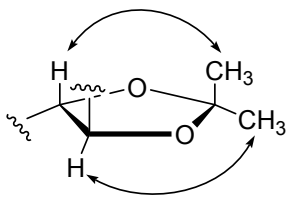

ROESY correlations of $\mathbf{1 a}$ and $\mathbf{3 a}$

ROESY correlations of $\mathbf{2 a}$ and $\mathbf{4 a}$

Scheme 1 Synthesis of di-O-isopropylidene derivatives $1 \mathbf{a} \sim \mathbf{4 a}$, and ROESY correlations of $1 \mathbf{a} \sim \mathbf{4 a}$
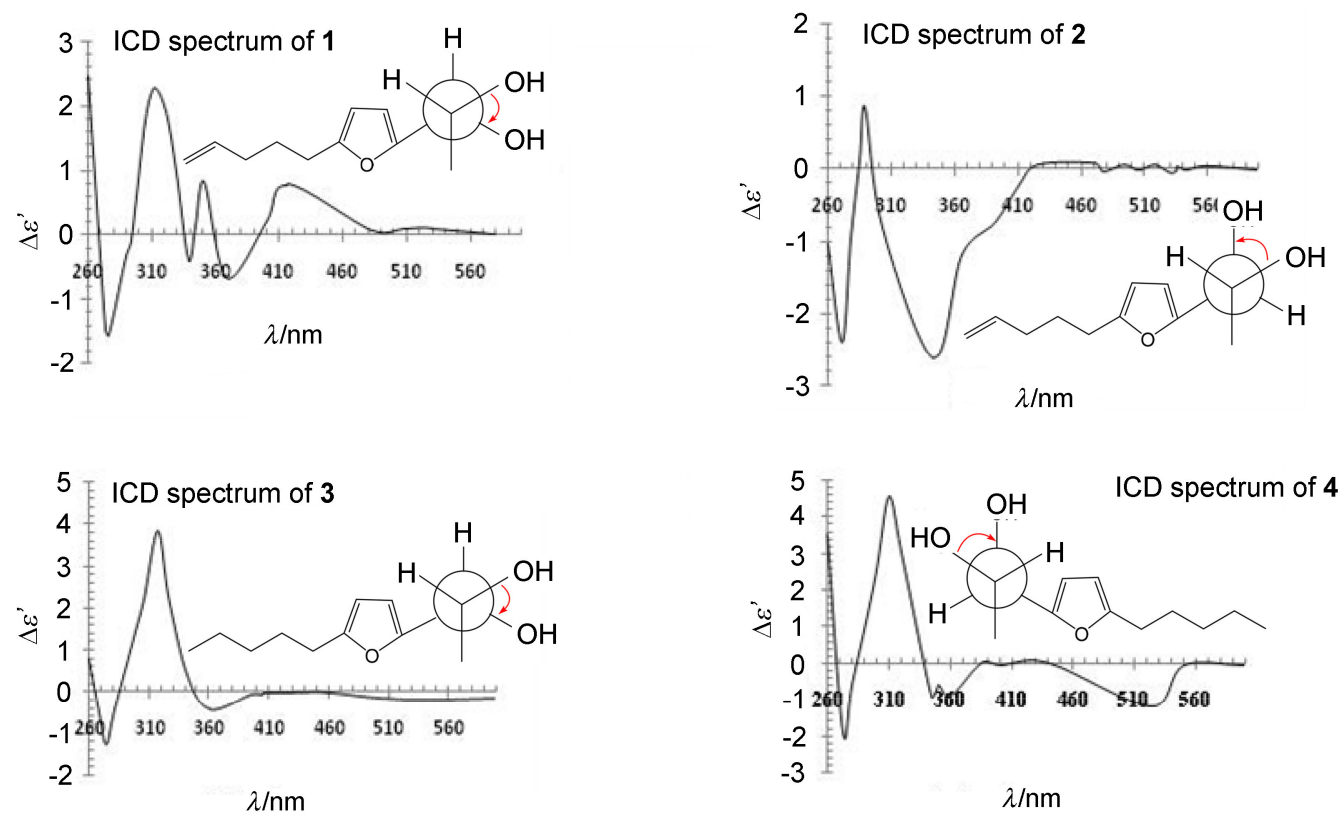

Figure 3 ICD spectra of compounds $\mathbf{1} \sim \mathbf{4}$ in solution of dimolybdenum tetraacetate in DMSO $\Delta \varepsilon^{\prime}$ was normalized on the diol concentration 


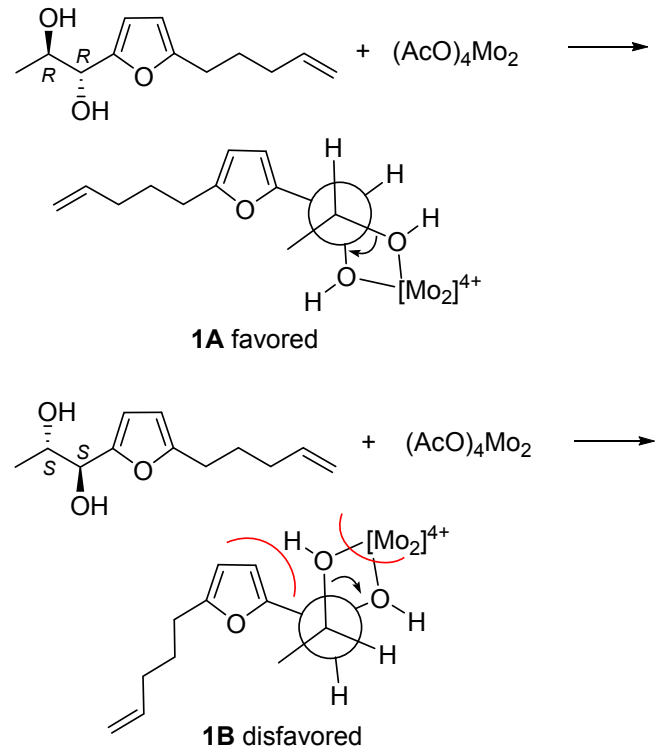

Scheme 2 Conformers $\mathbf{1 A}$ and $\mathbf{1 B}$ of compound 1 Conformer $1 \mathrm{~B}$ was disfavored because of the increased steric hindrance of the furan moiety

mined by chemical method and $\mathrm{Mo}_{2}(\mathrm{OAc})_{4}$ ICD experiment. It should be noted that $\mathrm{Mo}_{2}(\mathrm{OAc})_{4}$ ICD experiment is always inapplicable for non-terminal vicinal diols with a erythro-form, because the two substituents could not simultaneously be away from the $\mathrm{Mo}_{2}(\mathrm{OAc})_{4}$ in Newman projection. Fortunately, the two substituents (a furan moiety and a methyl) in this case varied largely in size, and thus, the larger furan moiety stay away from the $\mathrm{Mo}_{2}(\mathrm{OAc})_{4}$ to decrease the steric hindrance (Scheme 3). Eventually, the absolute configuration of the erythro-vicinal diols $\mathbf{1}$ and $\mathbf{3}$ was successfully determined. Compounds $\mathbf{1} \sim \mathbf{4}$ are four unusual 2,5-disubstituted furan derivatives with a $\mathrm{C}_{5}$-chain and a $\mathrm{C}_{3}$-diol moiety. From a biogenetic point of view, the presence of consecutive oxygenation in one terminal is interesting, and needs further investigation. This study provided valuable information for understanding the chemical diversity of Ceriporia alachuana, and determining the absolute configuration of vicinal diols.
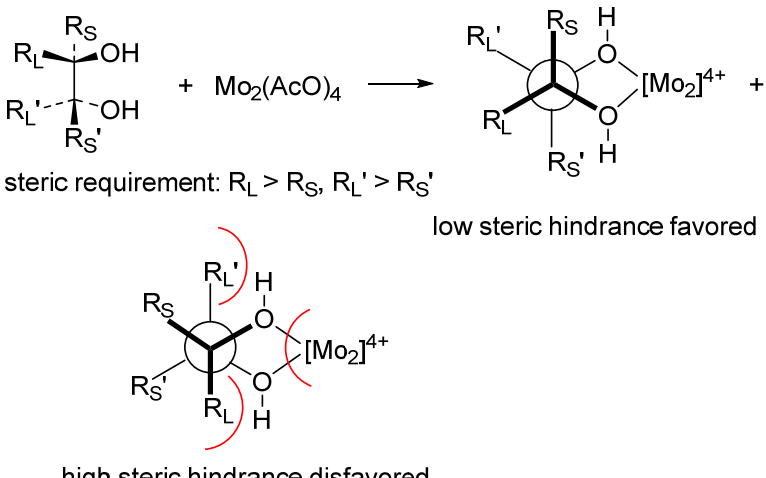

high steric hindrance disfavored

Scheme 3 Principle of the combination of vic-diol and $\mathrm{Mo}_{2}-$ $(\mathrm{OAc})_{4}$, and the steric effect of the groups connected with the $\mathrm{O}-\mathrm{C}-\mathrm{C}-\mathrm{O}$ moiety

\section{Experimental}

\subsection{General experimental procedures}

Optical rotations were recorded on a Jasco model 1020 digital polarimeter (Horiba, Tokyo, Japan). ECD spectra were performed on an Applied Photophysics Chira scan instrument (Agilent, Santa Clara, United States). Mass spectra were measured by a VG Autospec-3000 spectrometer (VG, Manchester, England). 1D and 2D NMR were recorded on AM-400 or DRX-500 spectrometer (Bruker, Bremerhaven, Germany). Silica gel $(200 \sim 300$ mesh, Qingdao Marine Chemical Inc., Qingdao, China), Sephadex LH-20 (Amersham Biosciences, Sweden), and RP-18 gel (40 $75 \mu \mathrm{m}$, Fuji Silysia Chemical Ltd., Japan) were used for column chromatography. Preparative HPLC (PrepHPLC) was performed on an Agilent 1100 liquid chromatography system equipped with a Zorbax SB-C18 column $(9.4 \mathrm{~mm} \times 150 \mathrm{~mm})$. Pre-coated silica gel GF254 plates (Qingdao Marine Chemical Inc., Qingdao, China) were used for monitoring fractions by thin-layer chromatography (TLC), and spots were visualized by heating plates after sprayed with $10 \% \mathrm{H}_{2} \mathrm{SO}_{4}$ in ethanol.

\subsection{Materials and cultivation}

The fungus was collected in Beijing Botanical Garden and identified as Ceriporia alachuana by Prof. Yucheng Dai (Beijing Forestry University). A voucher specimen (BJFC005267) was deposited in the Herbarium of Beijing Forestry University. The liquid culture medium for cultivation was consist of saccharine $(5 \%)$, yeast powder $(0.5 \%)$, peptone $(0.15 \%), \mathrm{KH}_{2} \mathrm{PO}_{4}(0.05 \%)$ and $\mathrm{MgSO}_{4}(0.05 \%)$. $C$. alachuana was inoculated in a 15 -literfermentor (Biostar, Shanghai Guoqiang, China) and incubated for $6 \mathrm{~d}$ under the following conditions: culture temperature $24{ }^{\circ} \mathrm{C}$, initial $\mathrm{pH}$ 6.0 , agitation speed $250 \mathrm{r} / \mathrm{min}$, inoculation volume $10 \%$, and aeration rate $1.0 \mathrm{vvm}$.

\subsection{Isolation}

The culture broth of $C$. alachuana $(20 \mathrm{~L})$ was filtered, and the filtrate was extracted with EtOAc for three times. The combined EtOAc parts ( $15 \mathrm{~g})$ was loaded on a silica gel column chromatography (CC) using a petroleum ether$\mathrm{Me}_{2} \mathrm{CO}$ gradient to afford fractions $\mathrm{A} \sim \mathrm{G}$. Fr.E was further separated by silica gel $\mathrm{CC}$ using $\mathrm{CHCl}_{3}-\mathrm{Me}_{2} \mathrm{CO}$ system to yield three subfracions $\mathrm{E} 1 \sim \mathrm{E}$ 3. Fr.E2 was subjected to Sephadex LH-20 CC and eluted by $\mathrm{MeOH}$ to generate fractions E2-1 and E2-2. Fr.E2-2 was initially separated on an Rp-18 gel column, then purified by preparative HPLC using $\mathrm{MeCN} / \mathrm{H}_{2} \mathrm{O}(V: V=40: 60 \rightarrow 70: 30)$ system to give compounds $\mathbf{1}(5.0 \mathrm{mg}), \mathbf{2}(7.5 \mathrm{mg}), \mathbf{3}(20.0 \mathrm{mg})$ and $\mathbf{4}$ (21.0 mg).

$(1 R, 2 R)$-1-(5-(Pent-4-en-1-yl)furan-2-yl)propane-1,2-diol (1): $[\alpha]_{\mathrm{D}}^{21}-17.3\left(c 0.10, \mathrm{CHCl}_{3}\right) ;{ }^{1} \mathrm{H}$ NMR $(400 \mathrm{MHz}$, acetone- $\left.d_{6}\right) \delta: 6.16(\mathrm{~d}, J=2.8 \mathrm{~Hz}, 1 \mathrm{H}, \mathrm{H}-5), 5.96(\mathrm{~d}, J=2.8$ $\mathrm{Hz}, 1 \mathrm{H}, \mathrm{H}-6), 5.88 \sim 5.78$ (m, 1H, H-11), 5.02 (d, $J=17.1$ $\mathrm{Hz}, 1 \mathrm{H}, \mathrm{H}-12 \mathrm{a}), 4.95$ (d, $J=10.2 \mathrm{~Hz}, 1 \mathrm{H}, \mathrm{H}-12 \mathrm{~b}), 4.44$ (d, $J=5.3 \mathrm{~Hz}, 1 \mathrm{H}, \mathrm{OH}-3), 4.28 \sim 4.24(\mathrm{~m}, 1 \mathrm{H}, \mathrm{H}-3), 3.99 \sim$ 3.95 (m, 1H, H-2), 3.59 (OH-2), 2.59 (t, $J=7.5 \mathrm{~Hz}, 2 \mathrm{H}$, 
H-8), $2.12 \sim 2.08$ (m, 2H, H-10), $1.70 \sim 1.68$ (m, 2H, H-9), $1.14(\mathrm{~d}, J=6.3 \mathrm{~Hz}, 3 \mathrm{H}, \mathrm{H}-1) ;{ }^{13} \mathrm{C}$ NMR $(100 \mathrm{MHz}$, acetone- $\left.d_{6}\right) \delta$ : $155.4(\mathrm{C}-4), 155.1$ (C-7), 139.1 (C-11), 115.2 (C-12), 107.8 (C-5), 106.2 (C-6), 72.9 (C-3), 70.1 (C-2), 33.8 (C-10), 28.1 (C-9), 27.9 (C-8), 18.8 (C-1); HREIMS calcd for $\mathrm{C}_{12} \mathrm{H}_{18} \mathrm{O}_{3} 210.1256$, found 210.1257 .

(1S,2R)-1-(5-(Pent-4-en-1-yl)furan-2-yl)propane-1,2-diol (2): $[\alpha]_{\mathrm{D}}^{21}-18.3\left(c 0.18, \mathrm{CHCl}_{3}\right)$; ${ }^{1} \mathrm{H}$ NMR $(400 \mathrm{MHz}$, acetone- $\left.d_{6}\right) \delta: 6.16(\mathrm{~d}, J=2.8 \mathrm{~Hz}, 1 \mathrm{H}, \mathrm{H}-5), 5.97(\mathrm{~d}, J=2.8$ $\mathrm{Hz}, 1 \mathrm{H}, \mathrm{H}-6), 5.84 \sim 5.82$ (m, 1H, H-11), 5.01 (d, $J=17.1$ Hz, 1H, H-12a), 4.94 (d, J=10.2 Hz, 1H, H-12b), 4.34 (d, $J=5.3 \mathrm{~Hz}, 1 \mathrm{H}, \mathrm{OH}-3), 4.26 \sim 4.22(\mathrm{~m}, 1 \mathrm{H}, \mathrm{H}-3), 3.92 \sim$ $3.90(\mathrm{~m}, 1 \mathrm{H}, \mathrm{H}-2), 3.86(\mathrm{OH}-2), 2.59$ (t, $J=7.5 \mathrm{~Hz}, 2 \mathrm{H}$, $\mathrm{H}-8), 2.09 \sim 2.11$ (m, 2H, H-10), $1.69 \sim 1.67$ (m, 2H, H-9), $1.00(\mathrm{~d}, J=6.3 \mathrm{~Hz}, 3 \mathrm{H}, \mathrm{H}-1) ;{ }^{13} \mathrm{C}$ NMR $(100 \mathrm{MHz}$, acetone- $\left.d_{6}\right) \delta$ : $155.8(\mathrm{C}-4), 154.6(\mathrm{C}-7), 139.1$ (C-11), 115.3 (C-12), 108.2 (C-5), 106.2 (C-6), 73.4 (C-3), 70.3 (C-2), 33.7 (C-10), 28.1 (C-9), 27.8 (C-8), 19.4 (C-1); HREIMS calcd for $\mathrm{C}_{12} \mathrm{H}_{18} \mathrm{O}_{3} 210.1256$, found 210.1255 .

$(1 R, 2 R)-1-(5-P e n t y l f u r a n-2-y l) p r o p a n e-1,2-d i o l$ $[\alpha]_{\mathrm{D}}^{21}-17.2\left(c\right.$ 0.35, $\left.\mathrm{CHCl}_{3}\right) ;{ }^{1} \mathrm{H}$ NMR (500 MHz, DMSO$\left.d_{6}\right) \delta: 6.08(\mathrm{~d}, J=3.0 \mathrm{~Hz}, 1 \mathrm{H}, \mathrm{H}-5), 5.96(\mathrm{~d}, J=3.0 \mathrm{~Hz}, 1 \mathrm{H}$, H-6), 5.15 (OH-3), 4.49 (OH-2), 4.22 (t, $J=5.6 \mathrm{~Hz}, 1 \mathrm{H}$, $\mathrm{H}-3), 3.78 \sim 3.74(\mathrm{~m}, 1 \mathrm{H}, \mathrm{H}-2), 2.53(\mathrm{t}, J=7.5 \mathrm{~Hz}, 2 \mathrm{H}$, $\mathrm{H}-8), 1.56 \sim 1.54$ (m, 2H, H-9), $1.31 \sim 1.19$ (m, 4H, H-10, 11), $1.06(\mathrm{~d}, J=6.3 \mathrm{~Hz}, 3 \mathrm{H}, \mathrm{H}-1), 0.86(\mathrm{t}, J=6.8 \mathrm{~Hz}, 3 \mathrm{H}$, $\mathrm{H}-12) ;{ }^{13} \mathrm{C}$ NMR (125 MHz, DMSO- $\left.d_{6}\right) \delta: 154.7$ (C-4), 154.1 (C-7), 106.5 (C-5), 105.1 (C-6), 71.4 (C-3), 68.5 (C-2), 30.8 (C-10), 27.3 (C-8 and C-9), 21.8 (C-11), 19.0 (C-1), 13.9 (C-12); HREIMS calcd for $\mathrm{C}_{12} \mathrm{H}_{20} \mathrm{O}_{3} 212.1412$, found 212.1416 .

$(1 R, 2 S)-1-(5-P e n t y l f u r a n-2-y l) p r o p a n e-1,2-d i o l$ $[\alpha]_{\mathrm{D}}^{21}-2.5$ (c $\left.0.30, \mathrm{CHCl}_{3}\right) ;{ }^{1} \mathrm{H}$ NMR $(400 \mathrm{MHz}$, DMSO- $\left.d_{6}\right) \delta: 6.11(\mathrm{~d}, J=2.8 \mathrm{~Hz}, 1 \mathrm{H}, \mathrm{H}-5), 5.97(\mathrm{~d}, J=3.0$ $\mathrm{Hz}, 1 \mathrm{H}, \mathrm{H}-6), 5.15$ (OH-3), $4.63(\mathrm{OH}-2), 4.14$ (t, $J=5.7 \mathrm{~Hz}$, $1 \mathrm{H}, \mathrm{H}-3), 3.75 \sim 3.71(\mathrm{~m}, 1 \mathrm{H}, \mathrm{H}-2), 2.54$ (t, $J=7.5 \mathrm{~Hz}, 2 \mathrm{H}$, $\mathrm{H}-8), 1.56 \sim 1.54$ (m, 2H, H-9), $1.29 \sim 1.27$ (m, 4H, H-10, 11), 0.89 (d, $J=6.3 \mathrm{~Hz}, 3 \mathrm{H}, \mathrm{H}-1), 0.85$ (t, $J=6.7 \mathrm{~Hz}, 3 \mathrm{H}$, $\mathrm{H}-12) ;{ }^{13} \mathrm{C}$ NMR (100 MHz, DMSO- $\left.d_{6}\right) \delta: 154.4(\mathrm{C}-4)$, 154.1 (C-7), 107.1 (C-5), 105.3 (C-6), 71.9 (C-3), 68.9 (C-2), 30.8 (C-10), 27.3 (C-8 and C-9), 21.9 (C-11), 19.2 (C-1), 13.9 (C-12); HREIMS calcd for $\mathrm{C}_{12} \mathrm{H}_{20} \mathrm{O}_{3} 212.1412$, found 212.1417 .

\subsection{Preparation of acetonides}

Compounds $\mathbf{1} \sim \mathbf{4}(2.0 \mathrm{mg})$ were dissolved in $2 \mathrm{~mL} \mathrm{DMF}$, respectively, then 2,2-dimethoxypropane (2 equiv. $2.1 \mathrm{mg}$ ) and $p$-TsOH ( 0.5 equiv., $0.9 \mathrm{mg})$ were added. The mixture was stirred at room temperature for $3 \mathrm{~h}$. The reaction was quenched by adding saturated aqueous $\mathrm{NaHCO}_{3}(5 \mathrm{~mL})$, and extracted with EtOAc $(5 \mathrm{~mL} \times 3)$. The combined organic layer was dried over $\mathrm{Na}_{2} \mathrm{SO}_{4}$ and concentrated in vacuo. The residue was subjected to silica gel $\mathrm{CC}$ using petroleum ether- $\mathrm{Me}_{2} \mathrm{CO}(V: V=95: 5)$ to afford respective acetonide.

\subsection{Measurements of the ICD spectra}

Samples were dissolved in appropriate DMSO (spectroscopy grade), respectively, which was used for the measurement of $\mathrm{CD}$ spectra $\left(\mathrm{CD}_{0}\right)$. Then, a quantity of $\mathrm{Mo}_{2}(\mathrm{OAc})_{4}$ were added to the solution with the ligand-to-metal ratio of approximately $1: 1.2$. After $30 \mathrm{~min}$, the $\mathrm{CD}$ spectra of the ligand-metal complex were further measured $\left(\mathrm{CD}_{1}\right)$. The induced $\mathrm{CD}$ (ICD) spectra were calculated from the $\mathrm{CD}$ of the ligand-metal complex $\left(\mathrm{CD}_{1}\right)$ deducting that of the vicinal diol sample $\left(\mathrm{CD}_{0}\right)$.

Supporting Information $1 \mathrm{D}$ and 2D NMR of compounds $1 \sim 4$. The Supporting Information is available free of charge via the Internet at http://sioc-journal.cn.

\section{References}

[1] Takatsuto, S.; Ikekawa, N. J. Chem. Soc., Perkin Trans. $1 \mathbf{1 9 8 3}$ 2133.

[2] Thadepalli, H.; Chuah, S. K.; Iskandar, L.; Gollapudi, S. Int. J. Antimicrob. Agents 2002, 20, 180.

[3] Nakakita, Y.; Nakagawa, M.; Sakai, H. J. Antibiot. 1980, 33, 514.

[4] Roush, W. R.; Hartz, R. A.; Gustin, D. J. J. Am. Chem. Soc. 1999, $121,1990$.

[5] Kolb, H. C.; Van Nieuwenhze, M. S.; Sharpless, K. B. Chem. Rev. 1994, 94, 2483.

[6] Harada, N.; Nakanishi, K. Acc. Chem. Res. 1972, 5, 257.

[7] Nakanishi, K.; Berova, N. Circular Dichroism: Principles and Applications, 2nd ed., Ed.: Woody, R. W., Weily-VCH, New York, 2000, Chapter 12.

[8] Bukhari, S. T. K.; Guthrie, R. D.; Scott, A. I.; Wrixon, A. D. Chem. Commun. 1968, 24, 1580.

[9] Bukhari, S. T. K.; Guthrie, R. D.; Scott, A. I.; Wrixon, A. D. Tetrahedron 1970, 26, 3653.

[10] Scott, I.; Wrixon, A. D. Chem. Commun. 1969, $20,1184$.

[11] Nakanishi, K.; Schooley, D. A.; Koreeda, M.; Dillon, J. Chem. Commun. 1971, 20, 1235.

[12] Dillon, J.; Nakanishi, K. J. Am. Chem. Soc. 1974, 96, 4055.

[13] Dillon, J.; Nakanishi, K. J. Am. Chem. Soc. 1975, 97, 5409.

[14] Frelek, J.; Ikekawa, N.; Takatsuto, S.; Snatzke, G. Chirality 1997, 9, 578.

[15] Bari, L. D.; Pescitelli, G.; Pratelli, C.; Pini, D.; Salvadori, P. J. Org Chem. 2001, 66, 4819.

[16] Xu, L. X.; He, Z. X.; Xue, J. H.; Chen, X. P.; Wei, X. Y. J. Nat. Prod. 2010, 73, 885.

[17] Liu, J.; Du, D.; Si, Y. K.; Lv, H. N.; Wu, X. F.; Li, Y.; Liu, Y. Y.; Yu, S. S. Chin. J. Org. Chem. 2010, 30, 1270. 